\title{
ORIGINAL ARTICLE High rates of relapse in adolescents crack users after inpatient clinic discharge
}

\author{
Alto índice de recaída em adolescentes usuários \\ de crack após a alta da internação \\ Rosemeri Siqueira Pedroso', Luciano Santos Pinto Guimarães', Luciana Bohrer Zanetello', Veralice Maria \\ Gonçalves', Ronaldo Lopes-Rosa', Thiago Pianca', Flavio Pechanky', Félix Herique Paim Kessler'
}

\section{Keywords}

Relapse, crack users, readmission,

post-treatment.

\section{ABSTRACT}

Objective: The objective of the present study was to evaluate 88 adolescent crack users referred to hospitalization and to follow them up after discharge to investigate relapse and factors associated with treatment. Methods: Cohort (30 and 90 days after discharge) from a psychiatric hospital and a rehab clinic for treatment for chemical dependency in Porto Alegre between 2011 and 2012. Instruments: Semi-structured interview, conducted to evaluate the sociodemographic profile of the sample and describe the pattern of psychoactive substance use; Crack Use Relapse Scale/CURS; Questionnaire Tracking Users to Crack/QTUC; K-SADS-PL. Results: In the first follow-up period (30 days after discharge), 65.9\% of participants had relapsed. In the second follow-up period (90 days after discharge), $86.4 \%$ of participants had relapsed. Conclusion: This is one of the first studies that show the extremely high prevalence of early relapse in adolescent crack users after discharge, questioning the cost/benefit of inpatient treatment for this population. Moreover, these results corroborate studies which suggested, young psychostimulants users might need tailored intensive outpatient treatment with contingency management and other behavioral strategies, in order to increase compliance and reduce drug or crime relapse, but this specific therapeutic modality is still scarce and must be developed in Brazil.

\section{RESUMO}

Objetivo: 0 objetivo do presente estudo foi avaliar 88 adolescentes usuários de crack no que se refere à hospitalização e dar-Ihes seguimento após a alta, para investigar as recaídas e os fatores associados ao tratamento. Métodos: Coorte (30 e 90 dias após a alta) de um hospital psiquiátrico e uma clínica de reabilitação, para o tratamento de dependência química em Porto Alegre, entre 2011 e 2012. Instrumentos: entrevista semiestruturada, realizada para avaliar o perfil sociodemográfico da amostra e descrever o padrão de uso de substâncias psicoativas; Escala de Recaída dos Usuários de Crack/ERUC; Questionário de Seguimento de Usuários de Crack/QSUC; K-SADS-PL. Resultados: No primeiro período de seguimento (30

1 Universidade Federal do Rio Grande do Sul (UFRGS), Hospital de Clínicas de Porto Alegre, Center for Drug and Alcohol Research.
Received in

$6 / 4 / 2016$

Approved in

$8 / 15 / 2016$

DOI: $10.1590 / 0047-2085000000127$
Address for correspondence: Rosemeri Siqueira Pedroso

Centro de Pesquisa em Álcool e Drogas Rua Prof. Álvaro Alvim, 400, Rio Branco 90420-020 - Porto Alegre, RS, Brazil Phone/fax: (55 51) 3359-6472

E-mail: rosemeripedroso@yahoo.com.br 


\section{Palavras-chave \\ Recaída, usuários de crack, readmissão, pós-tratamento.}

dias após a alta), 65,9\% dos participantes recaíram. No segundo período de seguimento (90 dias após a alta), 86,4\% dos participantes tiveram recaíram. Conclusão: Este é um dos primeiros estudos que mostram a prevalência extremamente alta de recaída precoce em adolescentes usuários de crack após a alta, questionando o custo-benefício do tratamento em regime de internação para essa população. Além disso, esses resultados corroboram estudos que sugerem que usuários de psicoestimulantes jovens podem precisar de um adaptado Tratamento Ambulatorial Intensivo, com manejo de contingências e outras estratégias comportamentais, a fim de aumentar a adesão, reduzir o uso da droga ou recaída ao crime. No entanto, essa modalidade terapêutica específica ainda é escassa e deve ser desenvolvida no Brasil.

\section{INTRODUCTION}

Crack use has spread extensively in Brazil starting at an early age. Currently, crack users are young people of all social classes. This happens because the drug can be easily purchased, and exposure usually occurs after alcohol and/or tobacco use'1. In spite of the significant number of adolescent crack user, there are very few studies of this sample.

A study found that, in the Brazilian capital cities, $0.11 \%$ of the $0.81 \%$ regular users of crack and/or similar drugs were children and adolescents and $0.70 \%$ of users were older than 18 years old. Of the 370 users of crack and/or similar drugs, approximately 50 (14\%) children and adolescents use crack in the Brazilian capital cities. About 28 (56\%) children and adolescents who use crack and/or similar drugs live in the capital cities of the Northeast region. Furthermore, in the capital cities of the South and North regions, about 3 children and adolescents use crack and/or similar drugs 2 .

Based on these figures, the number of annual hospitalizations in public hospitals for psychoactive substance use has been growing in the last four years according to Datasus ${ }^{3}$. However, there are few treatment options and they have not been proven effective so far. It seems that crack use relapse became part of the culture of the use of this psychoactive substance because users have adapted to its risks. And although crack users recognize the factors that have an influence on their relapse, they do not quit the drug ${ }^{4-9}$.

Crack use has increased dramatically in Brazil in recent times. Studies indicate different crack user relapse rates after hospital discharge $\mathrm{e}^{10-17}$. We believe that only an Intensive Outpatient Treatment ${ }^{18,19}$ could minimize early relapse after discharge.

Nevertheless, we could not find any study evaluating relapse as a specific outcome for crack users after hospital discharge ${ }^{20}$. Therefore, our study is the first one conducted with a sample of adolescent crack users. The objective of the present study was to report on the 30- and 90-day follow-up of this cohort after discharge.

\section{METHODS}

Study design: cohort.

\section{Sampling and selection process}

Ninety-four adolescents hospitalized voluntarily were evaluated in two psychiatric institutions located in Porto Alegre, between 2011 and 2012. In both psychiatric institutions treatment was specific to crack addiction psychiatric drugs and Cognitive Behavioral Therapy (CBT).

Of these, 4 patients were excluded from the study - 1 patient was psychotic and unable to complete the instruments; 2 patients denied using crack, although their urine test was positive for cocaine/crack; and 1 patient who lived in a shelter was prevented from participating in the study by legal advisors. Finally, 2 patients were lost to follow-up because not even their relatives or friends could be reached.

All participants had a DSM $5^{21}$ diagnosis of cocaine dependence - specifically, crack-cocaine dependence established by psychologists and psychiatrists the most prevalent form, specializing in drug dependence. All subjects reported crack as their drug of choice.

Final sample: 88 inpatient adolescent crack users.

\section{Procedures}

Initially, a team of psychology students was trained and supervised by experts in chemical dependency (psychiatrists and psychologists). Subsequently, the quality of data collection was measured by checking the research instruments before data were entered into the database.

\section{Instruments}

- Semi-structured interview: conducted to evaluate the sociodemographic profile of the sample and describe the pattern of psychoactive substance use, that is, to determine and record any other psychoactive substances that may have been used by the patients before beginning to use crack. 
- Crack Use Relapse Scale/CURS: a 25-item scale, each item consisting of a statement on factors that may influence crack use relapse ${ }^{22}$. Respondents are asked to read each item and circle the number that best describes how much they disagree or agree with each statement on a five-point Likert-type scale ${ }^{23}$ where 1 corresponds to "completely disagree" and 5, to "completely agree".

- Crack User Tracking Questionnaire/CUTQ: a questionnaire to track the trajectory of crack users after hospital discharge. It was created by the lead author of this study. Its questions are related to relapse and abstinence, attempted treatments, involvement in illegal activities, violence, employment, and school. The questionnaire was administered 30 and 90 days after discharge.

- TheK-SADS-PL (Kiddie-Schedulefor AffectiveDisorders and Schizophrenia for School-Aged Children - Present and Life time Version), validated Brazilian version ${ }^{24}$. Agreement between the interviewers was measured and evaluated using the Kappa index ${ }^{25}$ showing the following results: Depression - 0.80; Bipolar Disorder 0.76; ADHD (Attention Deficit/Hyperactivity Disorder) - 0.89; and Anxiety Disorders - 0.70. The patients' psychiatric diagnoses were established based on the interviews conducted by four medical students. The results of the interviews were reviewed by an experienced child and adolescent psychiatrist.

Logistics of the 30- and 90-day follow-up after discharge $(n=88)$.
Adolescent crack users and their parents/caregivers were informed that a member of our team would contact them one month and three months after discharge to perform a new interview.

Nevertheless, some patients did not return for the second interview even though they were offered a food basket as a way to encourage participation. The research team kept the phone numbers of the patients, their relatives, and close friends so that they could be reached whenever necessary. It was agreed that three attempts would be made to contact the patients and, if the patients could not be reached, a team member would make a home visit.

\section{Ethical aspects}

The study was approved by the Institutional Review Board of the Hospital de Clínicas de Porto Alegre.

\section{RESULTS}

Most participants were male. All of them were adolescents who had been hospitalized for treatment of crack use (Table 1).

\section{Analysis of data upon admission}

We performed an association analysis (chi-square test). Next, with the purpose of investigating the relationship of the CURS categories with relapse, we performed a Poisson regression analysis to evaluate the prevalence ratio between the categories using the CURS category "agreement" as reference (Table 2).

Table 1. Sociodemographic data and relapse comparing both sexes $(n=88)$

\begin{tabular}{|c|c|c|c|c|c|c|c|c|}
\hline \multirow{2}{*}{ Variable } & \multirow{2}{*}{ Categories } & \multirow{2}{*}{ N } & \multirow{2}{*}{$\%$} & \multicolumn{2}{|c|}{ Relapsed } & \multicolumn{2}{|c|}{ Did not relapse } & \multirow{2}{*}{ P } \\
\hline & & & & $n=76$ & $\%$ & $n=12$ & $\%$ & \\
\hline \multirow[t]{2}{*}{ Sex } & Female & 13 & 14.8 & 9 & 69.2 & 4 & 30.8 & 0.073 \\
\hline & Male & 75 & 85.2 & 67 & 89.3 & 8 & 10.7 & \\
\hline $\mathrm{Age}^{\mathrm{a}}$ & & 15.6 & 1.4 & 15.6 & 1.3 & 14.9 & 1.7 & 0.090 \\
\hline \multirow[t]{3}{*}{ Race } & White & 50 & 56.8 & 42 & 84.0 & 8 & 16.0 & 0.630 \\
\hline & Black & 17 & 19.3 & 16 & 94.1 & 1 & 5.9 & \\
\hline & Brown & 21 & 23.9 & 18 & 85.7 & 3 & 14.3 & \\
\hline \multirow[t]{6}{*}{ Educational level } & Illiterate & 1 & 1.2 & 1 & 100.0 & 0 & 0.0 & 0.768 \\
\hline & $1^{\text {st }}$ and $2^{\text {nd }}$ grades & 11 & 12.9 & 10 & 90.9 & 1 & 9.1 & \\
\hline & $3^{\text {rd }}$ and $4^{\text {th }}$ grades & 39 & 45.9 & 32 & 82.1 & 7 & 17.9 & \\
\hline & $5^{\text {th }}$ and $6^{\text {th }}$ grades & 26 & 30.6 & 23 & 88.5 & 3 & 11.5 & \\
\hline & $7^{\text {th }}$ and $8^{\text {th }}$ grades & 7 & 8.2 & 6 & 85.7 & 1 & 14.3 & \\
\hline & High school & 1 & 1.2 & 1 & 100.0 & 0 & 0.0 & \\
\hline \multirow[t]{2}{*}{ Socioeconomic status ${ }^{b}$} & Classes $A, B, C$ & 63 & 74.1 & 56 & 88.9 & 7 & 11.1 & 0.714 \\
\hline & Classes D, E & 22 & 25.9 & 19 & 86.4 & 3 & 13.6 & \\
\hline
\end{tabular}

Mean and SD.

${ }^{b}$ Classification according to the Brazilian Association of Market Research Institutes (Abipeme). 
Table 2. Comparison of the factors associated with relapse among adolescent crack users $(n=88)$

\begin{tabular}{|c|c|c|c|c|c|c|c|c|c|}
\hline \multirow{3}{*}{$\begin{array}{l}\text { CURS factors upon admission } \\
\text { Emotions, family, and affect }\end{array}$} & \multirow[b]{3}{*}{ Disagreement } & \multirow{2}{*}{\multicolumn{2}{|c|}{$\begin{array}{c}\text { Did not relapse } \\
n=12\end{array}$}} & \multirow{2}{*}{\multicolumn{2}{|c|}{$\begin{array}{c}\text { Relapsed } \\
n=76\end{array}$}} & \multirow{3}{*}{$p^{1}$} & \multicolumn{3}{|c|}{ Baseline CURS } \\
\hline & & & & & & & \multirow{2}{*}{$\begin{array}{c}\mathrm{PR}^{3} \\
0.99\end{array}$} & \multirow{2}{*}{$\frac{95 \% \mathrm{Cl}}{[0.75 ; 1.31]}$} & \multirow{2}{*}{$\frac{P^{2}}{0.960}$} \\
\hline & & 2 & 16.67 & 10 & 13.20 & & & & \\
\hline & Doesn't know & 1 & 8.33 & 19 & 25.00 & 0.532 & 1.13 & {$[0.97 ; 1.32]$} & 0.111 \\
\hline & Agreement & 9 & 75.00 & 47 & 61.80 & & 1.00 & & \\
\hline \multirow[t]{3}{*}{ Coping } & Disagreement & 2 & 16.67 & 11 & 14.50 & & 0.95 & {$[0.74 ; 1.23]$} & 0.704 \\
\hline & Doesn't know & 5 & 41.67 & 25 & 32.90 & 0.691 & 0.94 & {$[0.78 ; 1.14]$} & 0.507 \\
\hline & Agreement & 5 & 41.67 & 40 & 52.0 & & 1.00 & & \\
\hline \multirow[t]{3}{*}{ Health, sex, and treatment } & Disagreement & 4 & 33.33 & 14 & 18.4 & & 0.85 & {$[0.66 ; 1.11]$} & 0.229 \\
\hline & Doesn't know & 3 & 25.00 & 10 & 13.20 & 0.176 & 0.84 & {$[0.62 ; 1.15]$} & 0.278 \\
\hline & Agreement & 5 & 41.67 & 52 & 68.40 & & 1.00 & & \\
\hline \multirow[t]{3}{*}{ Legal and social aspects } & Disagreement & 6 & 50.00 & 20 & 26.30 & & 0.83 & {$[0.66 ; 1.04]$} & 0.098 \\
\hline & Doesn't know & 2 & 16.67 & 4 & 5.30 & 0.038 & 0.72 & {$[0.41 ; 1.27]$} & 0.255 \\
\hline & Agreement & 4 & 33.33 & 52 & 68.40 & & 1.00 & & \\
\hline \multirow[t]{3}{*}{ Positive expectations } & Disagreement & 1 & 8.33 & 13 & 17.10 & & 1.15 & {$[0.95 ; 1.39]$} & 0.163 \\
\hline & Doesn't know & 0 & 0.00 & 15 & 21.10 & 0.120 & 1.23 & {$[1.09 ; 1.40]$} & 0.001 \\
\hline & Agreement & 11 & 91.67 & 47 & 62.80 & & 1.00 & & \\
\hline \multirow[t]{3}{*}{ Craving } & Disagreement & 2 & 16.67 & 22 & 28.90 & & 1.18 & {$[0.97 ; 1.44]$} & 0.103 \\
\hline & Doesn't know & 0 & 0.00 & 18 & 25.00 & 0.048 & 1.29 & {$[1.10 ; 1.50]$} & 0.002 \\
\hline & Agreement & 10 & 83.33 & 35 & 46.10 & & 1.00 & & \\
\hline
\end{tabular}

${ }^{1} \chi^{2}$ test. ${ }^{2}$ Poisson regression analysis. ${ }^{3} \mathrm{PR}=$ prevalence ratio.

\section{Analyses of the 30- and 90-day follow-up}

In the first follow-up period (30 days after discharge), 65.9\% of participants had relapsed. In the second follow-up period (90 days after discharge), $86.4 \%$ of participants had relapsed. The mean time to relapse was 27 days $(\mathrm{SE}=3.78)$, and half of the participants relapsed within 10 days.

According to the CUTQ, 57 (64.8\%) patients completed the questionnaire related to the 30-day follow-up. On the $90^{\text {th }}$ day, 53 (60.2\%) patients completed the questionnaire. The remaining questionnaires were completed by family members, friends, shelter monitors, neighbors, or agents of the Child Protective Service.

\section{Comorbidities}

Our sample had significant comorbidities that may be associated with the amount of relapses identified in this study: Conduct Disorder (81\%); Oppositional Defiant Disorder (51\%); Attention Deficit/Hyperactivity Disorder (44\%); Separation Anxiety Disorder (21\%); Depressive Disorder (9\%); Generalized Anxiety Disorder (10\%); Specific Phobia (10\%) (Tables 3 and 4).

\section{Survival curve for relapse (Figure 1)}

Survival curve for Legal and Social Aspects: the mean time for relapse for those who agreed that this factor has an influence on relapse was shorter - mean of 19.93 days - compared to those who disagreed - mean of 37.50 days - or those who were not sure about the influence of this factor - mean of 38.03 days $(p=0.009)$.

Survival curve for Positive Expectations: the mean time for relapse for those who agreed that this factor has an influence on relapse was longer - mean of 33.44 days - compared to those who disagreed - mean of 13.27 days - or those who were not sure about the influence of this factor - mean of 13.5 days $(p=0.048)$.

Survival curve for Craving: the mean time for relapse for those who agreed that this factor has an influence on relapse was longer - mean of 34.18 days - compared to those who disagreed - mean of 22 days - or those who were not sure about the influence of this factor - mean of 16.68 days ( $p=$ 0.085).

\section{DISCUSSION}

Thirty days after discharge, $65.9 \%$ of the sample reported they had a relapse of crack use, and after 90 days of discharge, $86.4 \%$ had relapsed. The mean time of relapse was 27 days $(S E=3.78)$, and half of the participants relapsed within up to 10 days. We believe that 21 days of hospitalization are not enough to avoid early relapses after discharge because high relapse rates are an important outcome of the history of these patients showing very poor adherence to treatment ${ }^{5}$, even though outpatient treatment has been indicated. 
Table 3. Search for treatment in the public health system after hospital discharge and psychoactive substance abuse ( $\mathrm{n}=88$ )

\begin{tabular}{|c|c|c|c|c|c|c|}
\hline Variables & & 30 days & 90 days & Incident cases ${ }^{d}$ & Relapse cases ${ }^{e}$ & $\begin{array}{c}\text { Total in } 90 \text { days } \\
\%\end{array}$ \\
\hline \multirow{5}{*}{$\begin{array}{l}\text { Search for treatment in the public health } \\
\text { system (The same patient may have } \\
\text { sought treatment several times in the } \\
\text { period) }\end{array}$} & None & 36 & 60 & 30 & 30 & $66(75 \%)$ \\
\hline & Hospital & 25 & 11 & 5 & 6 & $30(34 \%)$ \\
\hline & Outpatient clinic & 14 & 1 & 1 & 0 & $15(17 \%)$ \\
\hline & CAPS $^{\mathrm{a}}$ & 8 & 7 & 4 & 3 & $12(14 \%)$ \\
\hline & Farm $^{b}$ & 5 & 9 & 6 & 3 & $11(13 \%)$ \\
\hline \multirow[t]{7}{*}{ SPA use (At least once) } & Alcohol & 42 & 44 & 6 & 38 & $48(55 \%)$ \\
\hline & Tobacco & 69 & 74 & 6 & 68 & $75(85 \%)$ \\
\hline & Marijuana & 49 & 24 & 5 & 19 & $54(61 \%)$ \\
\hline & Cocaine & 17 & 15 & 4 & 11 & $21(24 \%)$ \\
\hline & Crack & 73 & 80 & 7 & 73 & $80(91 \%)$ \\
\hline & Smoked alone & 6 & 4 & 0 & 4 & $6(7 \%)$ \\
\hline & Smoked in group & 82 & 84 & 2 & 82 & $84(95 \%)$ \\
\hline
\end{tabular}

CAPS $^{-}$- Center of Psychosocial Care. Farm ${ }^{b}$ - Therapeutic Community. SPAc - Psychoactive substance. Incident cases ${ }^{d}-$ First detection. Relapse cases - Second detection [difference between those cases detected in the 90 -day follow-up and the incident cases].

Table 4. Legal aspects $(n=88)$

\begin{tabular}{|c|c|c|c|c|c|c|}
\hline \multicolumn{2}{|l|}{ Variables } & \multirow{2}{*}{$\frac{30 \text { days }}{23}$} & \multirow{2}{*}{$\begin{array}{c}90 \text { days } \\
25\end{array}$} & \multirow{2}{*}{$\begin{array}{c}\text { Incident cases }^{\mathrm{a}} \\
9\end{array}$} & \multirow{2}{*}{$\frac{\text { Relapse cases }^{b}}{16}$} & \multirow{2}{*}{$\begin{array}{c}\begin{array}{c}\text { Total in } 90 \text { days } \\
\%\end{array} \\
32(36 \%)\end{array}$} \\
\hline Legal aspects & Committed crime after discharge & & & & & \\
\hline & Detention/Imprisonment after the last discharge & 4 & 1 & 0 & 1 & $4(5 \%)$ \\
\hline & Stealing & 9 & 8 & 1 & 7 & $10(11 \%)$ \\
\hline & Theft & 18 & 20 & 5 & 15 & $23(26 \%)$ \\
\hline & Drug dealing & 11 & 13 & 4 & 9 & $15(17 \%)$ \\
\hline & Possession of a firearm & 2 & 1 & 0 & 1 & $2(2 \%)$ \\
\hline & Robbery & 5 & 5 & 1 & 4 & $6(7 \%)$ \\
\hline & Vandalism & 1 & 1 & 0 & 1 & $1(1 \%)$ \\
\hline & None & 65 & 62 & 6 & 56 & $71(81 \%)$ \\
\hline
\end{tabular}

Incident cases ${ }^{\mathrm{a}}$ - First detection. Relapse cases ${ }^{\mathrm{b}}$ - Second detection [difference between those cases detected in the 90-day follow-up and the incident cases].

Our findings show that a short period of abstinence during hospitalization is only the beginning of a new process in the dynamics of crack dependence. In this context, psychosocial treatment should be included after discharge as a continuous process aimed at maintaining abstinence, considering that crack users often have to face several losses in different domains of their lives because of drug abuse ${ }^{5,26}$.

Our sample has different characteristics when compared to users of other drugs because, in addition to the clinical problems caused by crack use, patients also have to deal with a whole spectrum of psychosocial impairments after discharge. We agree with Watson and Gold ${ }^{27}$, who studied cocaine users in the 1980s and concluded that those patients with a shorter history of drug use and good functioning in other areas had better chances of abstinence.

In terms of coping, we found that crack users are aware of their inability to cope with a stressful problem (i.e., drug use), which is in agreement with previous studies ${ }^{20,27}$. In addition, crack users' poor health status enhances their likelihood to agree that the construct had an influence on their relapse, as suggested in the literature, considering that the patients' lifestyle (including feeding, sleep, and personal hygiene habits) may have a direct influence on the effects of physical and mental health 28,29 .

According to the chi-square analysis, the factor "legal and social aspects" was significant $(p=0.038)$. We found that $68 \%$ of those participants who agreed that this factor has an influence on relapse actually relapsed within 90 days after discharge. These findings suggest that the crack users who recognized legal and social aspects as factors that have an influence on relapse probably do so because they actually experience this problem in their daily lives and thus have worse survival, experiencing relapses within a shorter period of time after discharge. Conversely, those who recognize that positive expectations may have an influence on relapse probably start using strategies to deal with the triggers that can lead to relapse. Maybe this is the reason why they took longer to relapse when compared to those who disagree with the influence of positive expectations on relapse. Similarly, the participants who were unsure about the influence of this factor showed a prevalence of relapse $23 \%$ higher when compared to those who agree with this factor. 
A

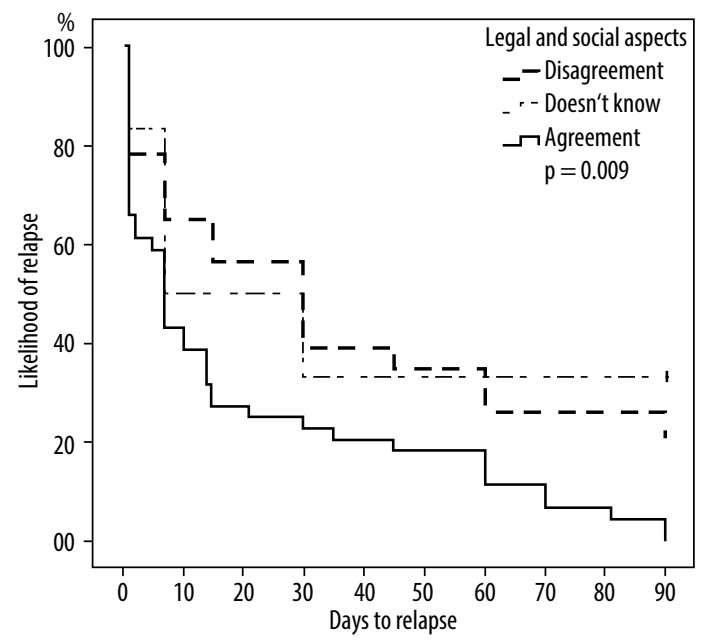

B

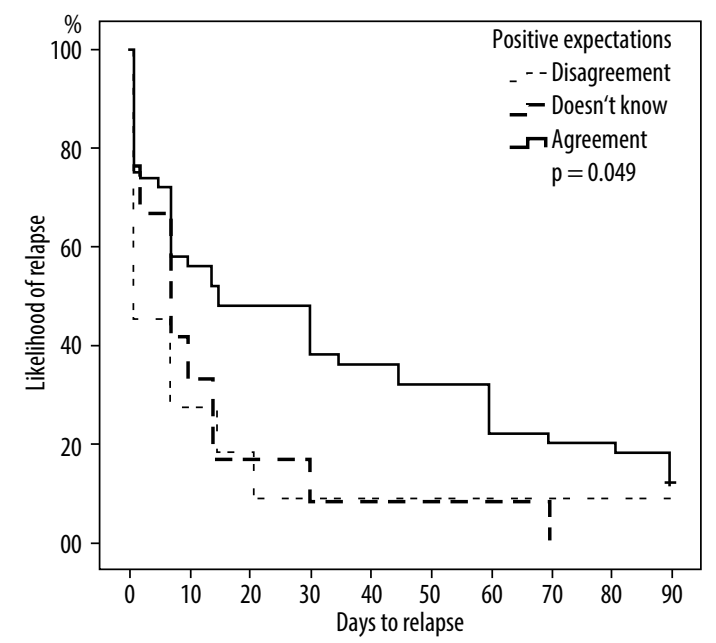

C

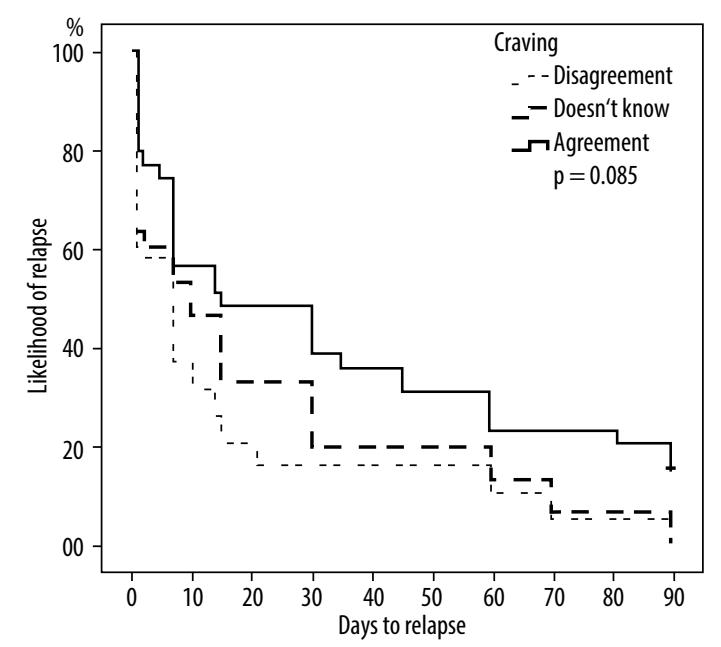

Figure 1. Survival curve for relapse $(n=88)$. (A) Survival curve according to legal and social aspects. (B) Survival curve according to positive expectations. (C) Survival curve according to craving.

We found that $83.33 \%$ of the participants who agreed that craving had an influence on relapse did not relapse within 90 days after discharge. It seems that acknowledging the influence of craving on relapse can help develop strategies to manage it more properly and remain abstinent for longer.

Our study has some limitations that deserve to be mentioned: the small size of the sample and the fact that most participants were male. While men have male units with specific programs to treat crack addiction, women are hospitalized with psychotic patients without any specific treatment for chemical addiction ${ }^{20}$. Such limitations prevent the generalization of our results. Another limitation is related to the follow-up interview. In some cases, the participant could not be reached and family member were interviewed instead. Therefore, we could not perform toxicological assessment based on urine test to confirm cocaine/crack use, and the results were based on other people's reports.

Our results suggest that a treatment based on shortterm hospitalizations, which is predominant in Brazil, is little effective to help patients maintain abstinence after discharge.

In our sample, only 25\% sought treatment after discharge. Most of them were hospitalized again and few sought outpatient treatment in the public health system. We also found that, in addition to crack, other drugs were used. The use of multiple substances is a characteristic of crack users described in a previous study ${ }^{30}$.

In terms of legal aspects, 32\% of participants were involved in criminal activities. When asked about these crimes, crack users associated them with the use of crack because when they were experiencing craving they could not control their behavior. However, we found that the comorbidities found in the present study are also important. The sample had Conduct Disorder (81\%) and Oppositional Defiant Disorder (51\%). It is important to note that Conduct Disorder and Attention Deficit Disorder/Hyperactivity Disorder may be associated with a higher number of relapses ${ }^{31,32}$.

We believe that longer treatments could help consolidate the dynamics of abstinence, which is in agreement with studies published in the $1990 \mathrm{~s}^{33-35}$. We do not believe that there is need to increase the length of hospital stay; instead, it is necessary to implement psychosocial followup after discharge. It seems essential to provide treatments that offer the patient with continuous support, either in outpatient clinics, centers of psychosocial care, therapeutic communities, shelters, self-help groups, or even religious organizations.

Hospitalization is just the beginning of treatment. It is not enough to treat crack addiction with just psychiatric drugs for detoxification and CBT to work motivation, craving management and relapse prevention. Our study showed that none of these measures were effective to prevent early relapse of crack users after discharge from hospital.

Our sample received outpatient treatment indication after discharge from hospital. However, not all crack users sought such services. And whenever they tried, they did not 
find an Intensive Outpatient Treatment ${ }^{18,19}$ that met the real needs after discharge, as mentioned in previous studies ${ }^{20,22}$ : the environment where the user lives and where he/she returns after discharge, old friendships, social isolation, vulnerability, violence, involvement in criminal activities, and unemployment.

\section{CONCLUSIONS}

It is clear that treatment should continue after discharge, because this is the only possibility of ensuring longer abstinence, which is very important for these drug users. Treatment must include all dimensions of a crack user's life instead of only addressing the disease ${ }^{26}$.

In order to maintain abstinence after hospital discharge, Intensive Outpatient Treatment ${ }^{18,19}$ is necessary, that treats the crack user in real life, outside the hospital, when often the crack user is unemployed, lives next to drug traffic, has no social and family support, in addition to comorbid conditions that we have indicated in previous studies ${ }^{20,22}$ as predictors of early relapse.

\section{INDIVIDUAL CONTRIBUTIONS}

Rosemeri Siqueira Pedroso - Managed data collection, conducted preliminary data analysis, drafted the manuscript, conducted final data analysis, and revised the manuscript.

Luciano Santos Pinto Guimarães - Carried out data interpretation, performed statistical analysis, and revised the manuscript.

Veralice Maria Gonçalves, Ronaldo Lopes-Rosa, and Thiago Pianca - Revised the manuscript.

Flavio Pechanky - Performed data interpretation, conducted preliminary data analysis, and revised the manuscript.

Félix Herique Paim Kessler - Designed the research questions and was responsible for general coordination and revision of the manuscript.

All authors read and approved the final manuscript.

\section{FINANCIAL SUPPORT}

Brazilian Secretariat for Drug Policies (SENAD), project number \# 10/0002.

\section{CONFLICTS OF INTEREST}

The authors have no competing interests.

\section{ACKNOWLEDGEMENTS}

Funding for this study was provided by the Brazilian Secretariat for Drug Policies (Senad), project number \# 10/0002; the Senad had no further role in the study design; collection, analysis, and interpretation of data; writing of the report; or in the decision to submit the paper for publication.

\section{REFERENCES}

1. Duailibi LB, Ribeiro M, Laranjeira, R. Profile of cocaine and crack users in Brazil. Cad Saúde Pública. 2008;24:545-57.

2. Bastos Fl, Bertoni N. Estimativa do número de usuários de cracke/ou similares nas Capitais do País, 2013. Available at: file:///C:/Users/Downloads/Livreto_Epidemiologico_17set\%20 (5).pdf.

3. MS/Datasus/SIH-SUS. Available at: http://tabnet.datasus.gov.br/cgi/tabcgi.exe?sih/cnv/ nirs.def. Acesso em: 13 abr. 2013.

4. Ribeiro LA, Sanchez ZM, Nappo SA. Estratégias desenvolvidas por usuários de crack para lidar com os riscos decorrentes do consumo da droga. J Bras Psiquiatr. 2010;59(3):210-8.

5. Ribeiro M, Laranjeira R. Tratamento do usuário de crack. 2. ed. Porto Alegre: Artmed; 2012.

6. Waisberg J, Porter J. Purpose of life and outcome of treatment for alcohol dependence. British Journal of Clinical Psychology. Br J Clin Psychol. 1994;33:49-63.

7. Edwards G, Dare C. Psicoterapia e tratamento de adições. Porto Alegre: Artes Médicas; 1997.

8. Marlatt GA, Gordon JR. Prevenção de recaída: estratégias de manutenção de comportamentos aditivos. Porto Alegre: Artes Médicas; 1993.

9. Rigotto SD, Gomes WB. Contextos de Abstinência e de Recaída. Psic.: Teor. e Pesq. 2002;18:95-106.

10. Chaney EE, O'Leary MR, Marlatt GA. Skill training with alcoholics. J Consult Clin Psychol. 1978;46:1092-104.

11. Laranjeira R, Dunn J, Rassi R, Mitsushiro SS, Fernandes MS. Seguimento de usuários de crack após dois anos. Rev Bras Psiquiatr. 1998;47(5):233-6.

12. Hser YI, Joshi V, Anglin MD, Fletcher B. Predicting posttreatment cocaine abstinence for first-time admissions and treatment repeaters. Am J Public Health. 1999;89(5):666-71.

13. Alterman Al, McKay JR, Mulvaney FD, Cnaan A, Cacciola JS, Tourian KA, et al. Baseline prediction of 7-month cocaine abstinence for cocaine dependence patients. Drug Alcohol Depend. 2000;59(3):215-21.

14. Sayette MA, Shiffman S, Tiffany S, Niaura R, Martin CS, Shadel W. The measurement of drug craving - Methodological aproaches to craving research. Addiction. 2000;2:189-210.

15. Siegal HA, Li L, Rapp RC. Abstinence trajectories among treated crack cocaine users. Addict behav. 2002;(27):437-49.

16. Gossop M, Marsden J, Stewart D, Kidd T. Changes in use of crack cocaine after drug misuse treatment: 4-5 year follow-up results from the National Treatment Outcome Research Study (NTORS). Drug Alcohol Depend. 2002;66(1):21-8.

17. Watkins KE, Hunter SB, Wenzel SL, Tu W, Paddock SM, Griffin A, et al. Prevalence and characteristics of clients with co-occurring disorders in outpatient substance abuse treatment. Am J Drug Alcohol Abuse. 2004;30:749-64.

18. McLellan AT. The outcomes movement in substance abuse treatment: Comments, concerns and criticisms. In: Sorenson J, Rawson R (eds.). Drug Abuse Treatment Through Collaboration: Practice and Research Partnerships That Work. Washington, DC: American Psychological Association Press; 2002. p. 119-34.

19. Budney AJ, Higgins ST. National Institute on Drug Abuse therapy manuals for drug addiction: Manual 2. A Community Reinforcement Plus Vouchers Approach: Treating Cocaine Addiction (NIH Publication No. 98-4309), 1998.

20. Pedroso RS, Kessler F, Pechansky F. Treatment of female and male inpatient crack users: a qualitative study. Trends Psychiatry Psychother. 2013;35:36-45.

21. American Psychiatry Association. Diagnostic and Statistical Manual of Mental disorders DSM-5. 5. ed. Washington: American Psychiatric Association; 2013. 
22. Pedroso RS, Pettenon M, Guimarães L, Kessler FHP, Pechansky F. The Crack Use Relapse Scale (CURS): development and psychometric validation. Rev Bras Psiquiatr. 2013;35:1-3.

23. Likert R. A technique for the measurement of attitudes. Arch Psychol. 1932;140-5.

24. Brasil HHA. Desenvolvimento da versão brasileira da K-SADS-PL (Schedule for Affective Disorders and Schizophrenia for School Aged Children Present and Lifetime Version) e estudo de suas propriedades psicométricas [tese de doutorado]. São Paulo: Universidade Federal de São Paulo. Escola Paulista de Medicina. Psiquiatria, 2003.

25. Medronho RA, et al. Epidemiologia. São Paulo: Editora Atheneu; 2004.

26. Dias AC, Ribeiro M, Dunn J, Sesso R, Laranjeira R. Follow-up study of crack cocaine users: situation of the patients after 2, 5, and 12 years. Subst Abuse. 2008;29:71-9.

27. Watson AM, Gold MS. Cocaine treatment: a guide. Newark, New Jersey: American Counci for Drug Education; 1986.

28. Valdez A, Cepeda A, Negi NJ, Kaplan C. Fumando la piedra: emerging patterns of crack use among Latino immigrant day laborers in New Orleans. I Immigr Minor Health. 2010;12:737-42.
29. Chaves TV, Sanchez ZM, Ribeiro LA, Nappo SA. Fissura por crack: comportamentos e estratégias de controle de usuários e ex-usuários. Rev Saúde Pública. 2011;45:1168-75.

30. Sanchez ZVDM, Nappo SA. Sequência de drogas consumidas por usuários de crack e fatores interferentes. Rev Saúde Pública. 2002;36:420-30.

31. Wilson JJ. ADHD and substance use disorders: developmental aspects and the impact of stimulant treatment. Am J Addict. 2007;16 Suppl 1:5-11; quiz 12-3.

32. Wilens TE, Morrison NR. The intersection of attention-deficit/hyperactivity disorder and substance abuse. Curr Opin Psychiatry. 2011;24:280-5.

33. Ferri CP. Cocaína: padrão de consumo e fatores associados à procura de tratamento [Dissertação de Doutorado]. São Paulo: Universidade Federal de São Paulo; 1999.

34. Dunn J, Laranjeira R. Cocaine: profiles, drug histories, and patterns of use of patients from Brazil. Subst Use Misuse. 1999:34:1527-48.

35. Bell DC, Richard AJ, Feltz LC. Mediators of drug treatment outcomes. Addict Behav. 1996;21:597-613. 